\title{
0988. Human neutrophil peptides play an important role in the pathogenesis of ARDS
}

\author{
F Pozzi ${ }^{1,2^{*}}$, M Parotto ${ }^{1}$, R Molinaro ${ }^{1}$, D Islam ${ }^{1}$, A Pesenti ${ }^{2}$, AS Slutsky ${ }^{1}$, H Zhang $^{1}$ \\ From ESICM LIVES 2014 \\ Barcelona, Spain. 27 September - 1 October 2014
}

\begin{abstract}
Introduction
Acute respiratory distress syndrome (ARDS) and ventilator induced lung injury (VILI) are characterized by neutrophil recruitment in the lung, and human neutrophil peptides (HNP) are the most abundant cationic proteins that are released into the extracellular matrix upon neutrophil activation. We and others have previously shown that high concentrations of HNP can lead to capillaryepithelial barrier damage in a mouse model of ARDS. We also demonstrated that VILI can lead to lung fibrotic development. We now extended the studies to examine the effects of HNP in lung remodeling.
\end{abstract}

\section{Objective}

Examine the role of HNP on lung remodeling in a mouse model of ARDS followed by mechanical ventilation.

\section{Methods}

Mice endogenously expressing $\mathrm{HNP}\left(\mathrm{HNP}^{+/+}\right)$were generated using a human neutrophil elastase promoter. The $\mathrm{HNP}^{+/+}$and the FVB wild type mice received either $\mathrm{HCl}$ $(\mathrm{pH}=1.0,3 \mathrm{~mL} / \mathrm{kg})$ intratracheally, or vehicle solution as a control. Respiratory system compliance, protein concentrations and differential cell counting in bronchoalveolar lavage fluid (BALF) were determined $48 \mathrm{~h}$ after $\mathrm{HCl}$. In a parallel experiment, the mice were randomized into 3 different groups $48 \mathrm{~h}$ after $\mathrm{HCl}: 1$ ) no mechanical ventilation; 2) low pressure mechanical ventilation for $2 \mathrm{~h}$; and 3) high pressure mechanical ventilation for $2 \mathrm{~h}$. The mice were then observed for 14 days for evaluation of epithelial damage, Ashcroft score for fibrosis and inflammation.

\section{Results}

The $\mathrm{HNP}^{+/+}$mice showed significantly body weight loss (Fig 1A), increased neutrophil count (Fig 1B) and enhanced total protein (Fig 1C) in BALF and decreased lung compliance (Fig 1D) at $48 \mathrm{~h}$ after $\mathrm{HCl}$ challenge, as compared to the FVB mice. The lung compliance remained low in $\mathrm{HNP}^{+/+}$mice 14 days after $\mathrm{HCl}$ instillation followed by mechanical ventilation at either low pressure or high pressure (Fig 1E).

\section{Conclusion}

HNP can accelerate inflammation at an early phase in a mouse model of $\mathrm{HCl}$-induced ARDS, which may contribute to lung remodeling at late phases, magnifying the deleterious effects of ventilator-induced lung injury. We are hoping to present a full picture regarding lung remodeling 14 days after receiving $\mathrm{HCl} /$ mechanical ventilation at the ESICM conference in September. 


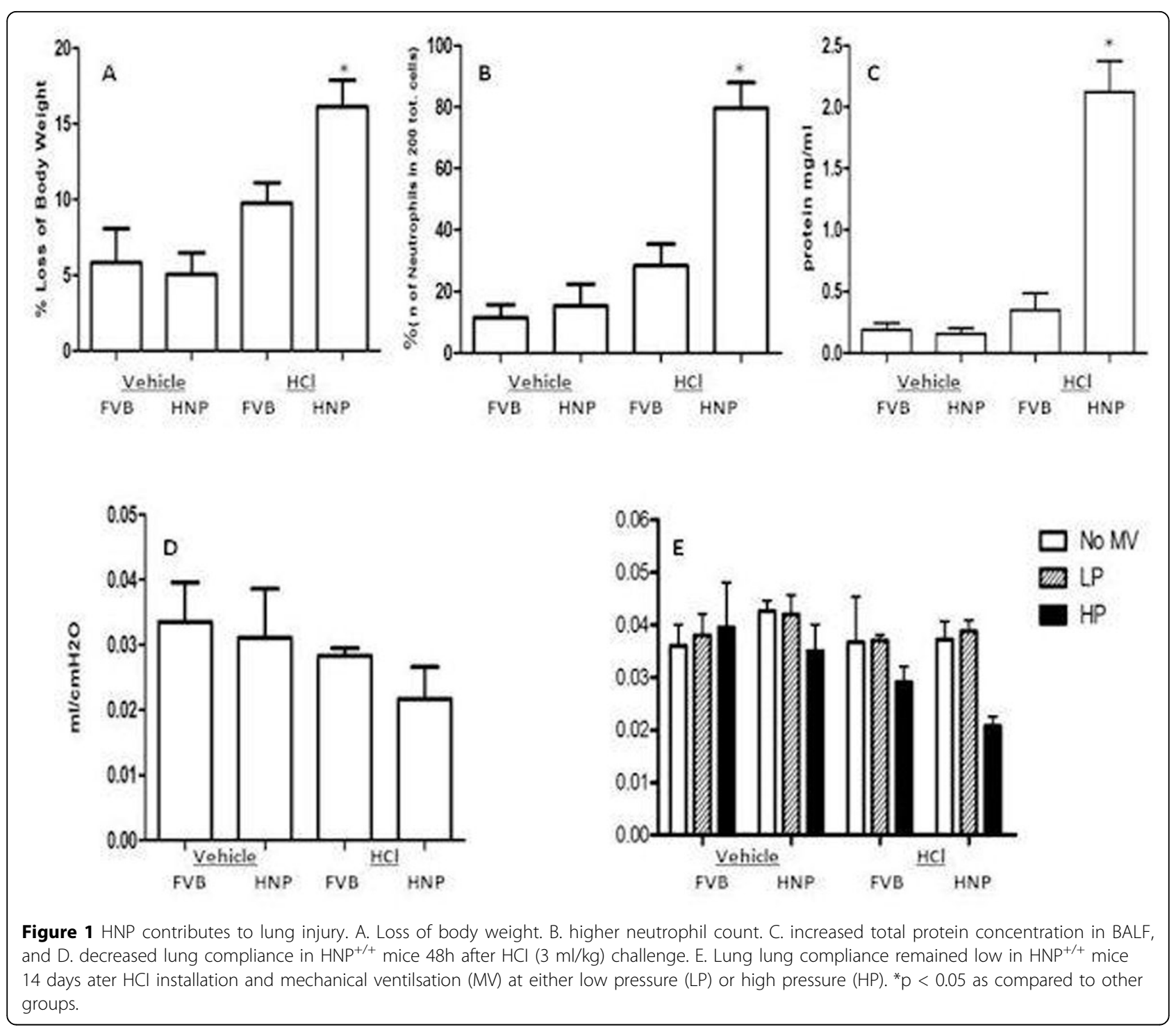

Grant acknowledgment

Canadian Institute of Health Research.

\section{Authors' details}

'Keenan Research Centre for Biomedical Science of St. Michael's Hospital,

Toronto, Canada. ${ }^{2}$ University of Milan - Bicocca, Milan, Italy.

Published: 26 September 2014

doi:10.1186/2197-425X-2-S1-P73

Cite this article as: Pozzi et al:: 0988. Human neutrophil peptides play an important role in the pathogenesis of ARDS. Intensive Care Medicine Experimental 2014 2(Suppl 1):P73.

Submit your manuscript to a SpringerOpen ${ }^{\circ}$ journal and benefit from:

- Convenient online submission

- Rigorous peer review

- Immediate publication on acceptance

- Open access: articles freely available online

- High visibility within the field

- Retaining the copyright to your article

Submit your next manuscript at $>$ springeropen.com 